\title{
Effect of Stage Compressive load on Single Pile Subjected to Time Effect: A Numerical Investigation
}

\author{
Kajal Tarenia ${ }^{1}$, Nihar Ranjan Patra ${ }^{1}$, Rajesh Sathiyamoorthy ${ }^{1}$, Apurba Mondal ${ }^{2}$ \\ ${ }^{1}$ Indian Institute of Technology, Kanpur, Department of Civil Engineering \\ Uttar Pradesh, India \\ kajal@iitk.ac.in; nrpatra@iitk.ac.in; hsrajesh@iitk.ac.in \\ ${ }^{2}$ Nuclear Power Corporation of India Ltd. \\ India \\ apurba@mpcil.co.in
}

\section{Extended Abstract}

The gradual process of construction by applying loads in increments to the foundation is called stage construction [3]. The experimental and numerical investigations on single pile and group piles considering time effect are limited. In the present study, the effect of stage compressive load on single pile considering time effect has been analysed by PLAXIS 3D [2]. The Mohr- Coulomb material model has been opted to represent the soil. The pile considered for analysis is $0.4 \mathrm{~m}$ in diameter and $8 \mathrm{~m}$ in length. Embedded pile option has been used to model the pile. The PLAXIS 3D [2] results have been validated by conducting a single pile stage compressive load test in the field. The field investigation has been carried out on a cast in-situ bored vertical pile to study the effect of compressive load on a single pile [3]. Two anchor piles are placed diagonally at a distance of $2.1 \mathrm{~m}$ each from the main pile. The anchor piles are $0.4 \mathrm{~m}$ in diameter and $10 \mathrm{~m}$ in length. The pile cage is of $0.3 \mathrm{~m}$ diameter consisting of 8 number of reinforcement steel bars (12mm diameter). Concrete of grade M25 has been used. Two diagonally opposite main reinforcement bars are instrumented with five electrical strain gauges. The subsoil exploration including sample collection and standard penetration test [4] has been carried out at an interval of $1.5 \mathrm{~m}$ up to a depth of $20 \mathrm{~m}$. The ground water table is found at depth of $7.5 \mathrm{~m}$. The soil mostly consists of $69 \%$ silt size and $30 \%$ sand size particles. The average density of soil is $16.5 \mathrm{kN} / \mathrm{m}^{3}$. The loading on the pile has been applied by a hydraulic jack of capacity 1000 ton. The pile is loaded vertically with gradual increment of loads. The load increment was 7.2ton in each step which is about $20 \%$ of the expected failure load. The initial portion of the load displacement curve is linear whereas at later stage it is non-linear in nature. The load distribution along the pile shaft is calculated from the strain readings. As the depth increases, the intensity of load distribution decreases along the pile shaft. The intensity of load distribution decreases up to 0.25 times the pile length and it is minimal thereafter. The load distribution remains constant at the bottom end of the pile. A comparison has been made between the observed load- displacement and with the predicted load-displacement response. After validation, further analysis has been carried out by subjecting the pile to a constant compressive load for a time duration of three months. It is observed that due to time effect, the settlement has been increased due to build-up of pore water pressure. The analysis has also been compared with the reported results [5] for single pile connected piled raft foundation. The reported analysis [5] was based on constant surcharge load. But in this analysis, constant load has been applied over a constant period of time. The results are useful for designing pile foundations considering time effect.

\section{Acknowledgement}

The authors are thankful to Board of Research in Nuclear Sciences (BRNS) for providing financial assistance.

\section{References}

[1] A. Shelke and N. R. Patra, "Effect of compressive load on uplift capacity of cast-insitu bored piles," Geotechnical and Geological Engineering, vol. 29, no. 5, p. 927, 2011.

[2] PLAXIS 3D 2013, Netherlands.

[3] IS: 2911 (Part1/Section2), "Code of practice for design and construction of pile foundations, Bored cast insitu piles," Bureau of Indian Standards (BIS) India, 1997. 
[4] Indian Standard-2131 (IS-2131), "Indian Standard, Method for Standard Penetration Test for Soils," 1981.

[5] K Tarenia and N. R. Patra, "Behaviour of Disconnected and Connected Piled Raft Foundations Subjected to Compressive Load," in Proceedings of the 4th World Congress on Civil, Structural, and Environmental Engineering, (CSEE'19), April 7-9, 2019, Rome, Italy.

[6] A. Wakai, S. Gose and K. Ugai, "3-D elasto-plastic finite element analyses of pile foundations subjected to lateral loading," Soils and Foundations, vol. 39, no. 1, pp.97-111, 1999.

[7] B. H. Fellenius, "Pile foundations," in Foundation engineering handbook, pp. 511-536. Springer, Boston, MA, 1991.

[8] R. Wade Brown and R. Brown, Practical foundation engineering handbook. New York: McGraw-Hill, 2001.

[9] C. J. Lee, M. D. Bolton and A. Al-Tabbaa, "Recent findings on negative skin friction in piles and pile groups in consolidating ground," in Proceedings of the 5th International Conference on Deep Foundations Practice, Singapore, pp. 273-280, 2001.

[10] K. Fleming, A. Weltman, M. Randolph and K. Elson, "Piling engineering," CRC press, 2008.

[11] H. G. Poulos, "An approximate numerical analysis of pile-raft interactions," International Journal for Numerical and Analytical Methods in Geomechanics, vol. 18, pp. 73-94, 1994.

[12] H. G. Poulos and Davis, E. H., "Pile foundation analysis and design," 1980.

[13] J. H. Lee and R. Salgado, "Determination of pile base resistance in sands," Journal of Geotechnical and Geoenvironmental Engineering, vol. 125, no. 8, pp. 673-683, 1999.

[14] L. Zhang, F. Silva and R. Grismala, "Ultimate lateral resistance to piles in cohesionless soils," Journal of Geotechnical and Geoenvironmental Engineering, vol. 131, pp. 78-83, 2005.

[15] M. F. Randolph, "Science and empiricism in pile foundation design," Geotechnique, vol. 53, no. 10, pp.847-875, 2003.

[16] R. Satyamurthy, M. S. Nataraj, K. L. McManis and G. P. Boutwell, "Investigations of pile foundations in brownfields," Journal of geotechnical and geoenvironmental engineering, vol. 134, no. 10, pp. 1469-1475, 2008.

[17] S. Karthigeyan, V. V. G. S. T. Ramakrishna and K. Rajagopal, "Numerical investigation of the effect of vertical load on the lateral response of piles," Journal of Geotechnical and Geoenvironmental Engineering, vol. 133, no. 5, pp.512$521,2007$.

[18] S. Karthigeyan, V. V. G. S. T. Ramakrishna and K. Rajagopal, "Influence of vertical load on the lateral response of piles in sand," Computers and Geotechnics, vol. 33, no. 2, pp. 121-131, 2006.

[19] X. Jiang and K. Li, "Research on Pull-out Mechanical Characteristics of Pile Foundation in Submerged Floating Tunnel," Procedia engineering, vol. 166, pp. 389-396, 2016. 